\title{
Understanding biological characteristics of Acacia melanoxylon in relation to fire to implement control measurements
}

\author{
Diego Arán ${ }^{1,2}$ • Juan García-Duro ${ }^{1}$ • Oscar Cruz $^{1} \cdot$ Mercedes Casal $^{1} \cdot$ Otilia Reyes $^{1}$ (i)
}

Received: 24 October 2016 / Accepted: 26 July 2017 / Published online: 14 August 2017

(C) INRA and Springer-Verlag France SAS 2017

\begin{abstract}
- Key message Acacia melanoxylon produces abundant seeds leading to large seed banks in the soil. These seeds display a large viability and their germination is stimulated by heat. To control the populations, it is necessary to remove adults and young individuals, and to prevent seedling establishment after fire occupying the space with rapid growth and high competitive native species.

- Context Acacia melanoxylon displays a widespread distribution in South West Europe, and an improved knowledge of its reproductive characteristics is required in order to control its expansion.

- Aims This experiment was designed to provide useful indicators for an efficient management of A. melanoxylon populations based on its biological cycle in relation to fire.
\end{abstract}

Handling Editor: Laurent Bergès

Contribution of the co-authors D. Arán performed all experiments and studies and wrote the manuscript.

J. García-Duro helped in the field and laboratory work and supervised the statistical analysis.

O. Cruz helped in the field work and contributed to the writing of the manuscript.

Mercedes Casal supervised the work experiment and revised the manuscript.

O. Reyes designed and coordinated the research project and revised the manuscript.

Otilia Reyes

otilia.reyes@usc.es

1 Área de Ecoloxía, Dpto. de Bioloxía Funcional, Facultade de Bioloxía, Universidade de Santiago de Compostela, 15782 Santiago de Compostela, Spain

2 Dpto. de Edafoloxía e Química Agrícola, Facultade de Bioloxía, Universidade de Santiago de Compostela, 15782 Santiago de Compostela, Spain
- Methods We explored the reproductive biology of A. melanoxylon, from seed dissemination — quantifying seed rain over a year, their germination with and without fire- the seedling and sapling banks and the structure of the adult population. We analysed the effects of fire, seed maturation and scarification on the viability of seeds and the stimulation of seed germination in the aerial seed bank and in the different strata of the soil seed bank.

- Results Our results indicate that A. melanoxylon produced millions of seeds per ha and per year, half of which germinated and the other half went to the soil seed bank, maintaining the viability many years. The germination was the most critical step in the population dynamics of this species, and fire stimulates germination up to $90 \%$.

- Conclusion A. melanoxylon adults and seedlings removal, followed by colonization of rapid growth and high competitive native species that cover the ground very quickly would be a good control action.

Keywords Black wattle · Germination - Seed dissemination · Seed banks $\cdot$ Tree population structure

\section{Introduction}

A great number of species of the Acacia genus (Global Invasive Species Database, GISD) are to be found among the invasive species that cause serious problems in ecosystems. Their most serious effects are the alteration of the structure and function of ecosystems and the homogenization of landscape (Lorenzo et al. 2010). One of the most important species of the Acacia genus due to its invasive potential and widespread distribution in the southwest of Europe is Acacia melanoxylon R.Br. (Australian blackwood). This is a species native to the temperate woods in southeast Australia and 
Tasmania (Bradbury et al. 2011; Searle 2000). It is a versatile tree with a great capacity for adaptation, which has spread all over the world above all due to its ornamental value (Knapic et al. 2006), economical value and colonizing potential, both in its native region (Jennings et al. 2003) and in other countries, such as Chile (Pinilla-Suárez et al. 2006), Portugal, Italy, France or Spain (Lorenzo et al. 2010). In South-Western Europe, forest plantations of this species began in the twentieth century and it is currently considered invasive both in Europe and other regions of the world (DAISE 2008; GISD 2016; Sanz-Elorza et al. 2004).

Climate change opens a way for new invasive species and increases the number and distribution of known invasive species. Climate change allows the movement of species to higher latitudes, and, on the other hand, it increases the frequency and intensity of fires. Also, many invasive species modify the fire regime (Mandle et al. 2011); moderate fires stimulate the germination of A. melanoxylon (Arán et al. 2013) and simultaneously leave areas free of competition, with much radiation and immediate fertility increase. Under these conditions, the fastest species, i.e. the most efficient in the use of resources, occupy the space and prevent the reestablishment of the preexisting plant community. They become invasive (Dick et al. 2014). A. melanoxylon quickly colonizes space and resources with the help of allelopathic competition (González et al. 1995). The competitive effect increases with the age of the individuals, because the phyllodes of $A$. melanoxylon generate allelophathic products which partially inhibit germination of other species while the allelopathic products from the flowers inhibit it completely (Hussain et al. 2011).

The great capacity of individuals of $A$. melanoxylon to establish in ecosystems is due to long-lasting individuals which generate vigorous resprouting from the root (Knapic et al. 2006) and show stimulation of germination due to fire (Jiménez et al. 2010; Arán et al. 2013). Also, this species possesses other functional features, such as producing an abundant, persistent and really resilient soil seed bank, which is one of the greatest obstacles to control the spread of this species in most parts of the world (Richardson and Kluge 2008). Moreover, it is difficult to handle Acacia species due to their tendency to invade ecosystems and crop areas, provoking serious problems in ecosystem services of preservation and production (Blaskesley et al. 2002).

In order to carry out control actions over a species, it is necessary to understand its biological characteristics (Moya et al. 2007), especially those that allow it to invade and dominate a community. The seeds of A. melanoxylon are classified according to O'Dowd and Gill (1986) as type B seeds, that is, adapted for ornithochory, with a prominent and coloured aril and a semi-permeable testa; they are also dispersed by air or water. They also present primary dormancy that is easily broken by scarification (Richardson and Kluge 2008). Even though they present several dispersal mechanisms, most of the seeds of the Acacia species are accumulated below or really close to the crown of the mother plants (Milton and Hall 1981; Walters and Milton 2003). Some recent studies described the main ecological impacts of Acacia species (Le Maitre et al. 2011), and others focused on some characteristics of their reproductive biology (Gibson et al. 2011; StiehlAlves and Martins-Corder 2006; Reyes et al. 2015b; Wujeska-Klause et al. 2015), but a more in-depth knowledge of the reproductive characteristics of $A$. melanoxylon is needed in order to construct and improve methodologies and performances to control invasive species. For this reason, the main aims of this study were (1) to know more about the reproductive characteristics of $A$. melanoxylon and (2) to define handling criteria to manage the invasive species. These two objectives were achieved through the following specific goals: (i) to determine the abundance and structure of an adult population and its soil seed bank, (ii) to describe the viability of seeds in both aerial and soil seed banks, (iii) to quantify the production and annual distribution of the seed rain, (iv) to determine the effect of fire on the germination of seeds from the aerial and soil seed banks and also of seed maturation and scarification on germination of aerial seed bank, and (v) to quantify seedling recruitment and re-sprout saplings.

\section{Material and methods}

The research was performed in an adult population of A. melanoxylon, which is representative of many other populations of South Western Europe: Pedroso population which occupies a surface of 2.5 ha, in Monte Pedroso, Santiago de Compostela, Spain, (ETRS89 29T 535246 4748227, central UTM coordinates). The average altitude of the Pedroso population is $310 \mathrm{~m}$ a.s.1. The climate is oceanic, warm and rainy (average annual temperature $13{ }^{\circ} \mathrm{C}$, average annual rainfall $1816 \mathrm{~mm}$ ). The soil is an Umbric Leptosol, little developed and acidic soil ( $\mathrm{pH} \approx 4.5$ ) developed from granitic materials, where the exchange complex is dominated by $\mathrm{Al}$ and surface horizon is rich in soil organic matter. Forest workers make sporadic cuttings of underwood vegetation, the last cutting occurred in December 2012.

\subsection{Density and structure of the adult population}

In March 2012, adult population density and structure of A. melanoxylon was determined, setting up 7 sampling plots of $25 \mathrm{~m} \times 25 \mathrm{~m}$ (Méndez et al. 2015). In those plots, the number of trees above $2.5 \mathrm{~cm}$ DBH was counted and DBH measurements were taken of all the trees present in the samples. 


\subsection{Soil seed bank}

In order to study the abundance and structure of the soil seed bank, 30 cores of $5 \mathrm{~cm}$ of depth and $4 \mathrm{~cm}$ in diameter were randomly distributed in the study area (Ferrandis et al. 1999). Each one of these cores was divided into three depths: 1 (litter), $2(0-2 \mathrm{~cm})$ and $3(2-5 \mathrm{~cm})$. The samples were sieved at $1.4 \mathrm{~mm}$ and the number of present seeds was recorded. This study was carried out in March-April 2012, before the seed rain cycle and underwood cutting.

\subsection{Aerial seed bank and seed production}

To quantify the aerial seed bank and register the time distribution of seed dispersal, 30 fixed quadrats $(50 \times 50 \mathrm{~cm})$ were randomly placed on the Pedroso soil during March 2012 and samples were extracted on a monthly basis over a year. In each sample, the legume pods of A. melanoxylon, generally open in two valves, were picked up. To calculate the number of seeds per surface unit, the number of seeds per valve was also counted in a total of 200 valves (100 pods). Thus, monthly values were obtained as well as the yearly total of seeds per $\mathrm{m}^{-2}$. With data coming from seeds valve ${ }^{-1}$ and valve $\mathrm{m}^{-2}$ together with the projection on the soil of the tree crown of the population, density of seeds of the aerial seed bank (seeds individual ${ }^{-1}$ ) was calculated. For that, the following equation was applied:

Aerial seed bank $=\left(\frac{n}{2}\right) * s * p$

where $n$ is the number of valves collected (valves $\mathrm{m}^{-2}$ )

$\mathrm{S}$ is the average number of seeds per pod ( $\operatorname{seeds} \operatorname{pod}^{-1}$ )

$\mathrm{P}$ is the average projection on the soil of the adult units $\left(\mathrm{m}^{2}\right.$ individual $^{-1}$ ), obtained through visual estimates.

The distribution of seed rain over a year was also calculated, expressed as number of seeds unit ${ }^{-1}$ of this population and number of seeds $\mathrm{m}^{-2}$.

\subsection{Seed viability}

Seed viability was determined for both the aerial and the soil seed banks. A tetrazolium test for seed viability was used (Calvo et al. 2016), following the guidelines established by ISTA (2007): 5 replicates of 25 seeds were incubated in 9-cmdiameter Petri dishes to which $10 \mathrm{ml}$ of $1 \%$ chloride 2,3,3triphenyl tetrazolium were added. After 2 days in the dark, seeds with a reddish embryo were considered viable.

\subsection{Germination}

Two treatments were applied to the seeds: a control and a thermal treatment of $80{ }^{\circ} \mathrm{C}-10 \mathrm{~min}$. The choice of thermal treatment was based on a previous study (Arán et al. 2013), as the one that most stimulated germination. In addition, two treatments were applied to the seeds of the aerial bank: mechanic scarification with cutter and maturation, because both are related to breaking dormancy in leguminous species. To simulate the effect of maturation, the seeds were maintained in the dark at about $25{ }^{\circ} \mathrm{C}, 50 \% \mathrm{RH}$ for 2 years.

Following Reyes and Trabaud (2009), 5 replicates of 25 seeds each were made with the seeds of each soil level and treatment. To ensure the independence of the replicates, each one was exposed to thermal treatment in isolation. The seeds were incubated in a Phytotron (ClimasAGP890) keeping them for $16 \mathrm{~h}$ with light at $24^{\circ} \mathrm{C}$ and $8 \mathrm{~h}$ of darkness at $16^{\circ} \mathrm{C}$ (Rivas et al. 2006; Arán et al. 2013; Reyes et al. 2015a). Germination, considered as the emergence of the radical was registered each Monday, Wednesday and Friday in a row until germination was completed, 2 months later.

The final germination was expressed as percentage and time needed to reach $50 \%$ of germination $\left(\mathrm{T}_{50}\right)$ in days (Reyes and Casal 2006). It was ensured that the data met the assumptions of the ANOVA and for that, the data of percentage of germination were arcsine transformed. The obtained data were analysed using several univariate analyses (ANOVAs). In those cases where the ANOVAs showed significant differences, a Duncan test was carried out with $p<0.05$ to find out which treatments were different from control. The software used was "PASW Statistics 18" for Windows.

\subsection{Bank of seedlings and re-sprout saplings}

In order to know how many seeds incorporated to the soil can actually become new individuals of the population each year, the number of seedlings existing in the population 10 months after the underwood cutting was determined and a difference was established between the seedlings emerged that year and those from the previous year which had re-sprouted.

The slash was done in December 2012 and the sampling of seedlings and re-sprouted seedlings in September 2013. To that aim, we performed 65 samples of $50 \mathrm{~cm} \times 50 \mathrm{~cm}$ in which all present seedlings and non-re-sprouting individuals were counted (Reyes et al. 2015a). Also, the spatial distribution of seedlings in the population was evaluated.

With the information of each phase of the biological cycle studied, we drew a projection towards the future of two scenarios: with and without fire. The fire scenario was inferred from the experiment and literature. It was assumed that fire destroyed the aerial seed bank and acted on levels 1 and 2 (in the same manner as $80^{\circ} \mathrm{C}-10 \mathrm{~min}$ ) of soil seed bank but not on 
level 3. In without fire scenario, the germination came from seed control of the aerial seed bank plus the corresponding one to each level of the soil seed bank.

\section{Results}

\subsection{Abundance and structure of the adult population}

The density of the adult population of A. melanoxylon taking into account all individuals with a DBH over $2.5 \mathrm{~cm}$ was $201 \pm 17$ individuals $\cdot \mathrm{ha}^{-1}$. The average DBH for the adult population was $43.9 \pm 1.8 \mathrm{~cm}$. Pedroso population had a very large percentage of individuals allocated in intermediate classes (DBH between 40 and $45 \mathrm{~cm}$ ).

\subsection{Density and structure of the soil seed bank}

The soil seed bank was very abundant and reached $44 \times 10^{3}$ seeds $\mathrm{m}^{-2}$; the number of seeds increased with increasing soil depth (Fig. 1): the two deeper levels displayed significant differences with the litter level $(p<0.001)$.

\subsection{Viability}

The viability of seeds from the aerial bank was $95.2 \%$. In the soil seed bank, the viability was above $92 \%$ (Table 1 ). The adult individuals were over 30 years old, and some of the seeds of the soil bank could be about 25 years old. These data confirm that the soil seed bank of A. melanoxylon is resilient over time, and it also preserves all the viability of the seeds when released from their mother plant.

\subsection{Aerial seed bank and seed production}

The aerial seed bank was very abundant, 10,900 seeds $\mathrm{m}^{-2}$ year ${ }^{-1}$, but it is not persistent over time because all seeds produced are dispersed in the same year (personal

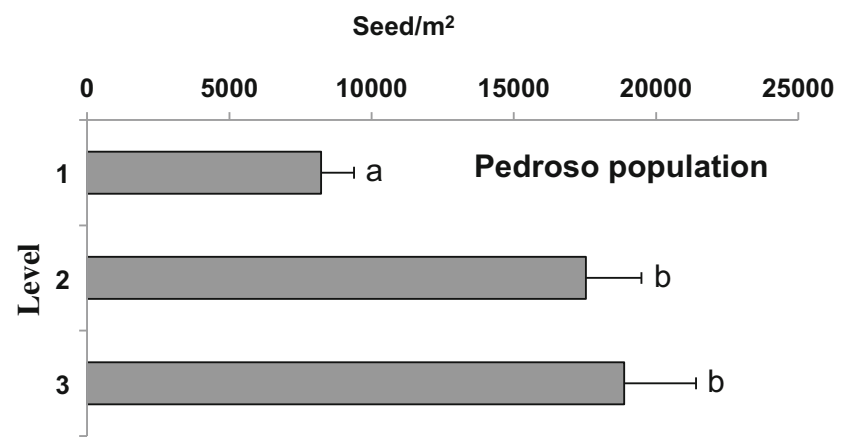

Fig. 1 Vertical structure of the soil seed bank of A. melanoxylon population of Pedroso in the three established levels. Different letters next to the error bars indicate significant differences between levels. 1 litter, $20-2 \mathrm{~cm}, 32-5 \mathrm{~cm}$
Table 1 Percentage of viability of seeds of A. melanoxylon present in the aerial seed bank and in the three levels selected from the soil seed bank, 1: litter, $20-2 \mathrm{~cm}, 32-5 \mathrm{~cm}$, of Pedroso population

\begin{tabular}{lll}
\hline & Level & Viability (\%) \\
\hline Aerial Bank & & 95.2 \\
Soil Bank & 1 & 97.6 \\
& 2 & 92.0 \\
& 3 & 95.0 \\
\hline
\end{tabular}

observation). The number of seeds per pod was high and constant $(9.37 \pm 0.26)$. Average seed production was 543,000 seeds individual ${ }^{-1}$ year $^{-1}$. The seed rain was continuous throughout the year (Fig. 2), although an increase in the number of seeds occurred between August and December $(p<0.05)$. The highest value was reached in December 2012 with $115 \times 10^{3} \pm 8.7 \times 10^{3}$ seeds individual ${ }^{-1}$ and the lowest during July with $9.04 \times 10^{3} \pm 1.5 \times 10^{3}$ seeds individual $^{-1}$.

\subsection{Germination}

The percentage of seed germination from the aerial seed bank was moderate (53.6\%, Table 2). Freshly fallen seeds increased their germination after thermal treatment, reaching $71.2 \%$ (Fig. 3), a significant difference compared to the control seeds $(p<0.05)$. After maturation in laboratory conditions, the seeds from the aerial seed bank increased germination a little compared to control and reached $64.0 \%$. The scarified seeds showed an increase in their germination, reaching a value of $72.0 \%$ (Fig. 3 and Table 2). Significant differences between control and scarified seeds were detected $(p<0.05)$; however, the difference between control and seeds matured over 2 years was not significant.

The germination of control seeds from the soil seed bank was very low in the three depth levels studied and in all of them, it increased a lot with thermal treatment (Fig.4 and Table 2). Seed germination increased by over $80 \%$ in all cases. No difference was detected among soil depths neither in controls nor in heat-treated samples.

The temporal distribution of germination was different in the seeds from each seed bank (Fig. 3 and Fig. 4). Seeds from the aerial bank took about 15 days to germinate and even 4 months later, some germination was still taking place; however, soil seeds, both control and those treated with thermal shock, started to germinate sooner, in about 5 days, and after 1 month, germination was almost finished. In the aerial seed bank, the seeds that presented a more similar behaviour to the soil bank seeds were the scarified seeds, since they presented a similar pattern to the heated seeds from any soil level. The largest difference in germination patterns took place in the soil 
Fig. 2 Temporal distribution of seed rain individual ${ }^{-1}$ throughout a year. The months with the highest seed rain have been shaded. The shaded area is significantly different from the non-shaded area

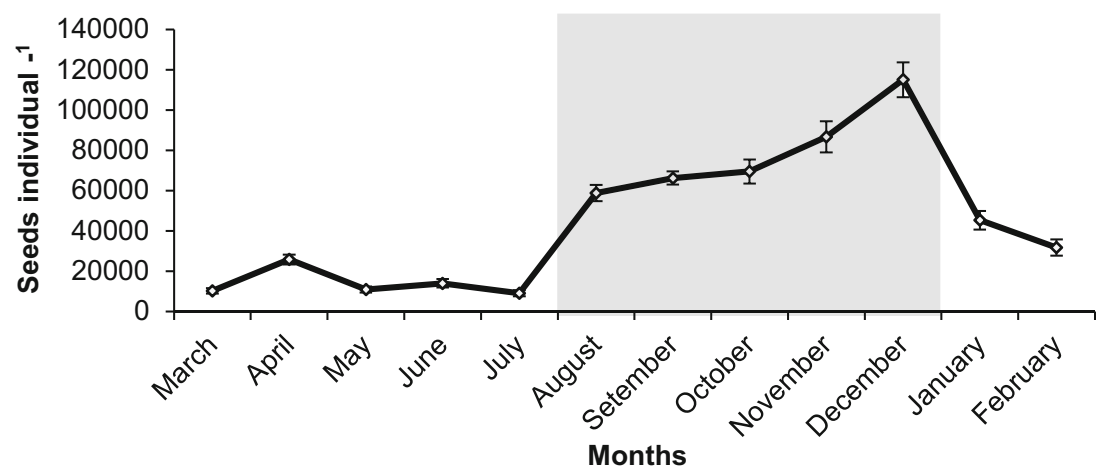

seed bank, between control and thermal treatment. The first presented flat curves over time, whereas the latter presented abundant early germinations, concentrating the highest increments between days 5 and 20 of the experiment.

The $\mathrm{T}_{50}$ of the aerial seed bank was much larger than the $\mathrm{T}_{50}$ of the soil seed bank (Table 2). Despite the differences in $\mathrm{T}_{50}$, only scarification provoked a significant advance in mean germination time.

\subsection{Seedling and re-sprouting sapling banks}

The density of seedlings of $A$. melanoxylon was very high, $124.6 \pm 14.4$ seedlings $\mathrm{m}^{-2}$. The distribution of seedlings was heterogeneous and varied between less than 50 and 500 seedlings $\mathrm{m}^{2}$. The spatial distribution of seedlings displayed an aggregate pattern.

Regarding re-sprouting saplings, $3.0 \pm 0.7$ saplings per $\mathrm{m}^{-2}$ were found. The frequency distribution shows that the majority $(18 \%)$ of the quadrats contain 4 or less re-sprouting saplings $\mathrm{m}^{-2}$. The other groups of seedling density were much less frequent, and $14 \%$ of the quadrants presented between 10

Table 2 Germination percentage and average germination time, in days, $\left(\mathrm{T}_{50}\right)$ reached by control seeds and seeds exposed to thermal treatment, maturation or scarification belonging to both seed banks of A. melanoxylon

\begin{tabular}{lllll}
\hline & Level & Treatment & Germination (\%) & $\mathrm{T}_{50}$ (days) \\
\hline Aerial bank & & Control & 53.6 & 31.6 \\
& & $80^{\circ} \mathrm{C}-10 \mathrm{~min}$ & 71.2 & 30.2 \\
& & Maturation & 64.0 & 43.3 \\
& & Scarification & 72.0 & $10.4^{\mathrm{a}}$ \\
Soil bank & \multirow{2}{*}{1} & Control & 6.1 & 14.2 \\
& & $80{ }^{\circ} \mathrm{C}-10 \mathrm{~min}$ & 89.4 & 16.8 \\
& \multirow{2}{*}{2} & Control & 3.1 & 22.0 \\
& & $80{ }^{\circ} \mathrm{C}-10 \mathrm{~min}$ & 91.2 & 11.8 \\
& \multirow{2}{*}{3} & Control & 10.3 & 12.8 \\
& & $80{ }^{\circ} \mathrm{C}-10 \mathrm{~min}$ & 92.8 & 12.4 \\
\hline
\end{tabular}

Levels of the soil seed bank: 1 litter, $20-2 \mathrm{~cm}, 32-5 \mathrm{~cm}$

${ }^{a}$ Significant differences with control and 24 re-sprouting saplings $\mathrm{m}^{-2}$. The remaining $5 \%$ of the quadrants presented between 5 and 9 re-sprouting saplings $\mathrm{m}^{-2}$ (Fig. 5b).

\section{Discussion}

In the studied population of A. melanoxylon, the older trees predominated, which lead us to think that the population would not persist. However, making a projection into the future of two scenarios with or without fire based on the number of individuals in each period of the biological cycle of A. melanoxylon (seed banks, recruitment of seedlings, and saplings), we found that the population could continue to survive and colonize new areas.

The soil seed bank was very abundant and delved deeper into the ground, which is common in mature populations. The increase in seed density with increasing soil depth and the clear separation of the litter from the rest of the soil indicates a bank persistent over time (Ferrandis et al. 2011). The total soil seed bank contained about 44,640 seeds $\mathrm{m}^{-2}$, a density very similar to that found on the same species by Milton and Hall (1981) in South Africa. A big seed bank like this one made up of seeds with high viability (approximately 95\%) and which may remain dormant for 50 years or longer (Holmes 1989; Leino and Edqvist 2010) implies a strong resilience of the population and is an obstacle for an efficient and sustainable management of $A$. melanoxylon in many parts of the world (Richardson and Kluge 2008). A marge storage in the soil seed bank will perpetuate the population because the buried seeds are better isolated from the fluctuations in surface temperature, and they can stay longer in a latent physical state (Richardson and Kluge 2008).

The annual production of seeds was very high $(543,000$ seeds individual ${ }^{-1}$ year $^{-1}$ ), that is an approximate density of 10,900 seeds $\mathrm{m}^{-2}$ year ${ }^{-1}$. Similar densities were registered in Portugal in different populations of A. longifolia (Labill.) Wendl. (Marchante et al. 2010). However, the production of seeds greatly varies within and across species, areas, habitats and years (Lorenzo et al. 2010). Thus, the value of seed production obtained in this research was between 3 and 10 
Fig. 3 Temporal distribution of germination of the seeds from the aerial seed bank of Pedroso population exposed to the treatments: Control, thermal treatment $\left(80^{\circ} \mathrm{C}-10 \mathrm{~min}\right)$, maturation and scarification

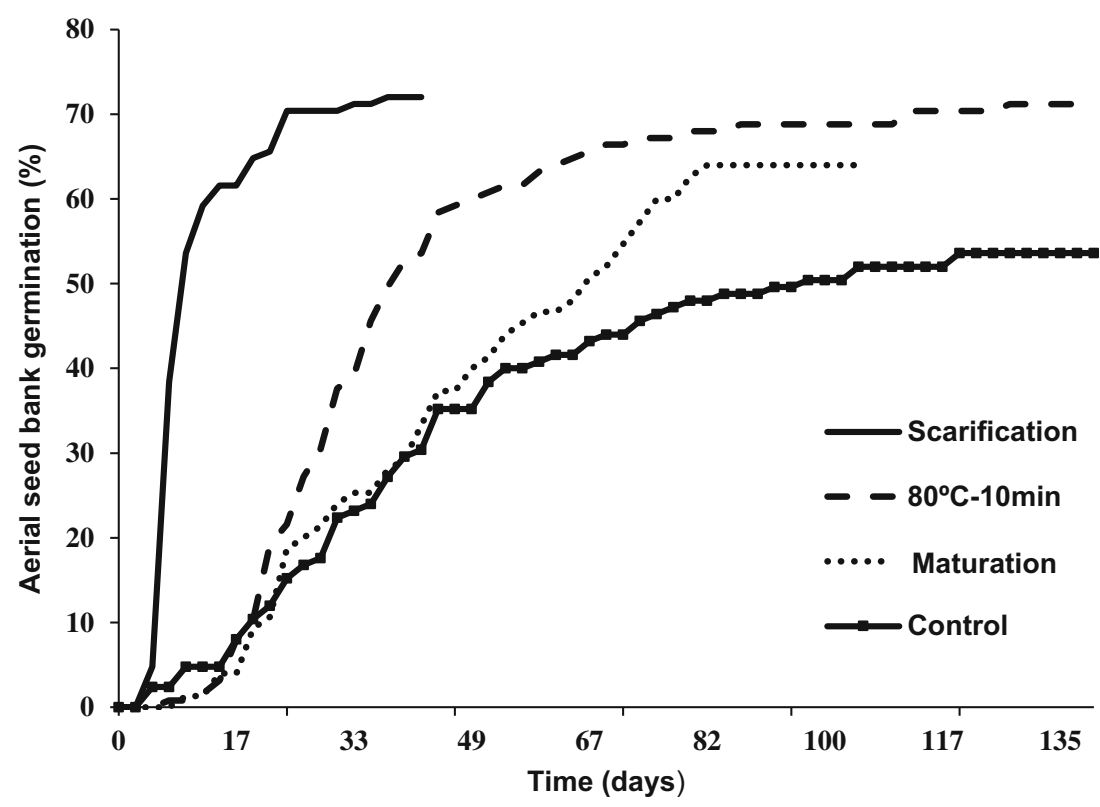

times higher than that obtained by Gibson et al. (2011) in populations of A. melanoxylon in the Southern hemisphere, where fructification efficiency is normally low; less than $1 \%$ of the flowers of A. cyclops G. Don, A. longifolia, A. podalyriifolia A.Cunn. ex Don, A. melanoxylon and Acacia saligna (Labill.) H. Wendl. produced mature pods (Milton and Hall 1981).

The seed rain was abundant throughout the year but not uniform. If we take almost 11,000 dispersed seeds, about a fourth of these seeds were lost in its transition to the litter. The loss of these seeds could have been due to animal predation (rodents, ants, birds, etc.), rotting and germination of the seeds, and to a much lesser extent, to other types of disturbances (erosion). Thus, the three fourths of the annual seed rain joined the active soil seed bank (Fig. 6).

The high seed germination in the aerial seed bank indicated the existence of two groups of seeds in the aerial seed bank: (a) those with immediate germination and (b) those that somehow remain dormant. Thermal shock and mechanic scarification released a good part of dormant seeds, but $25 \%$ of viable seeds could present other type of dormancy, which may be only released after going through the soil seed bank. Most of the seeds that go into the soil seed bank are dormant and thus, since there are no external stimuli, there is little germination at each of the depth levels. Seed viability was high, which corroborates the high degree of dormancy; between 85 and $91 \%$ of the seeds in the soil were latent. This behaviour was also observed by Marchante et al. (2010) in A. longifolia. In this species, the germination percentage did not exceed $12 \%$. This high dormancy guarantees the soil seed bank to possess many seeds ready to germinate after a disturbance breaks the state of physical latency. This germination response to moderate thermic shocks was already observed in this species (Arán et al. 2013). Similar results were found in other species of the same genus (Bell 1999) and in other species of the same family (González-Rabanal and Casal 1995; Rivas et al. 2006; Reyes and Trabaud 2009).

The soil seed bank is a dynamic system in constant flow, receiving seed input with aggregate distribution over space and time, as shown in this study, mainly from nearby plants
Fig. 4 Temporal distribution of seed germination from the soil seed bank exposed to control and thermal treatment

$\left(80{ }^{\circ} \mathrm{C}-10 \mathrm{~min}\right)$, for each one of the three established levels

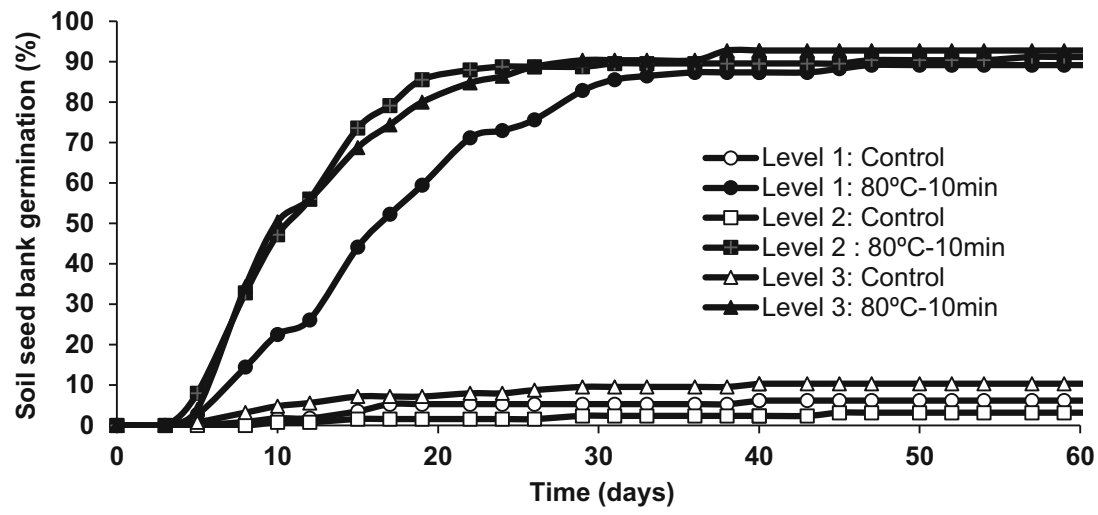


Fig. 5 Seedling frequency $\mathrm{m}^{-2}$

(a) and re-sprouting saplings $\mathrm{m}^{-2}$

(b) present in the studied

population 10 months after clear

cutting the understory

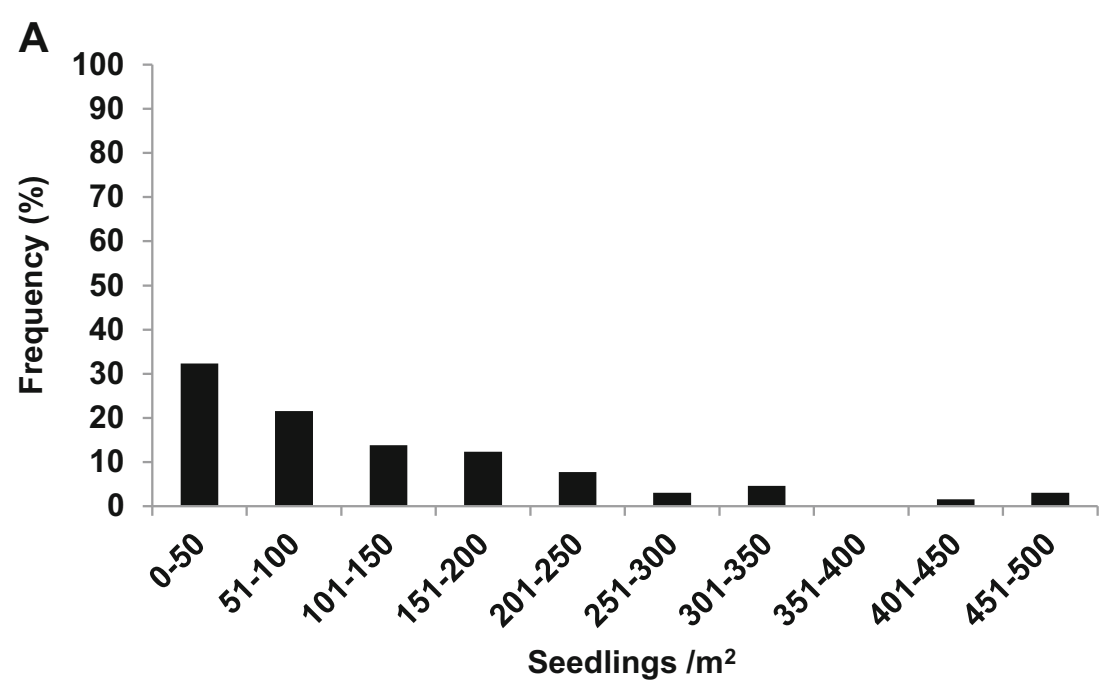

B

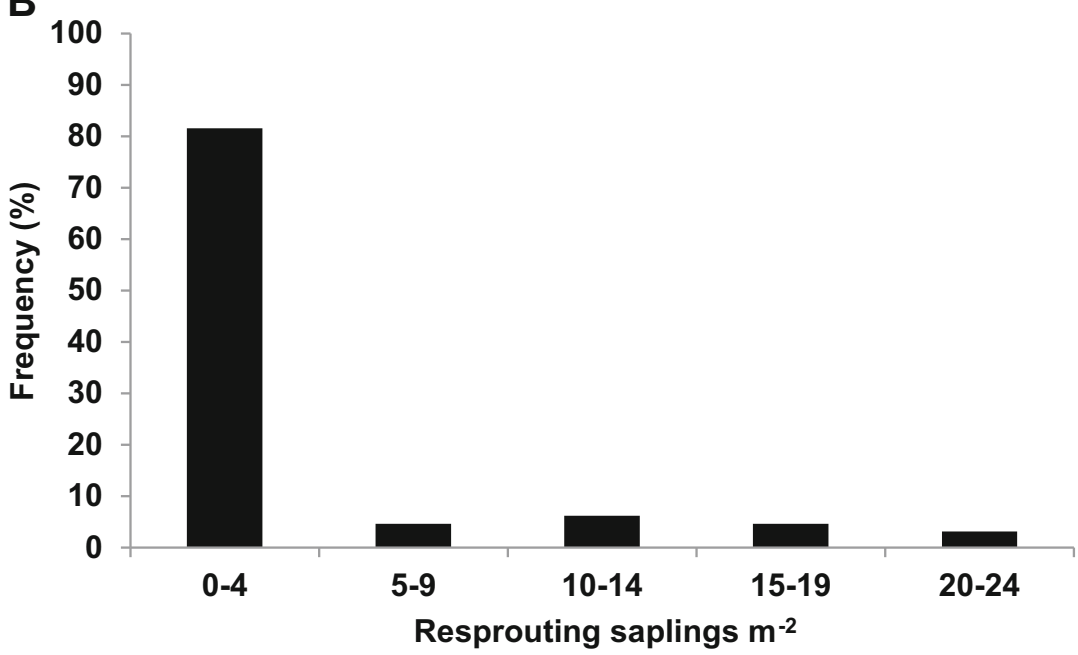

(Marañon 2001). Regarding the seeds in the bank, only a small fraction can germinate. If we take into account just the annual production, the percentage of seeds becoming seedlings is $1.4 \%$, whereas if we take into account the total number of seeds in the soil seed bank, we observe that this percentage is reduced, becoming just $0.1 \%$. Therefore, the recruitment of new individuals was low relative to the abundance of the soil seed bank. The majority of these seedlings, or all of them, will not survive in a mature population such as this one, because the resources are completely captured by adult individuals. On the other hand, this low population recruitment can also be explained by the intense resprouting experienced by $A$. melanoxylon. Due to its capacity to resprout, the settlement of seedlings in the areas already colonized by the species is not essential for the perpetuation of the population. In this population, the density of resprouting saplings was below 3 resprouting saplings $\mathrm{m}^{-2}$. Likewise, the majority of these resprouting saplings will not reach adulthood except when gaps were opened by falling trees. At the moment, the adult population correspond to $0.02 \%$ of seedling population, but taking into account the multiple generations of seedlings that became living adults, that percentage must be even smaller.

In the fire scenario, the aerial seed bank will become unviable whereas the most superficial seed bank will be stimulated. The high temperatures of a fire only penetrate the most superficial part of the soil, approximately the litter and level 2 of the soil (Bradstock and Auld 1995), then the germination of seeds from the soil bank could generate 25,219 seedlings $\mathrm{m}^{-2}$, that is, three times more than in the absence of fire, and keeping the same transition rate from the germination stage to the establishment stage, the establishing seedlings could be 354 seedlings $\mathrm{m}^{-2}$. If the population would reach the density of the adult population of this study, then the transition rate from the establishment stage to adult population would be $0.006 \%$.

The information provided in this study unveils the high invasive potential of $A$. melanoxylon while showing the self- 


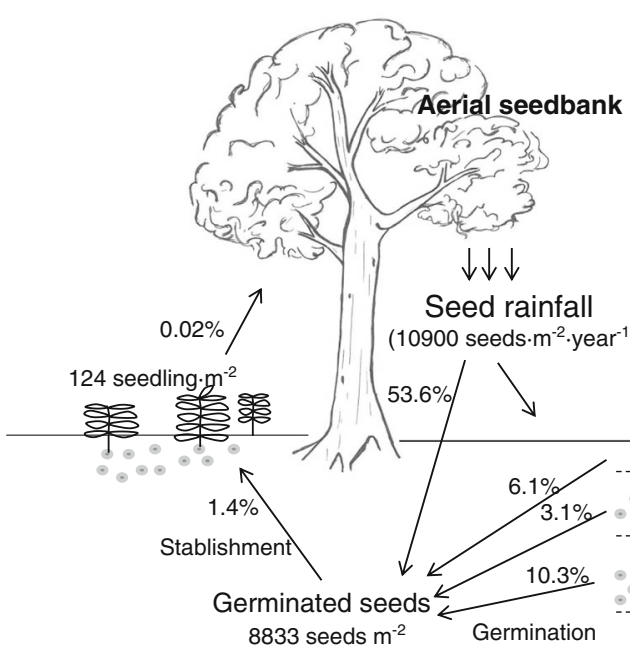

Before fire

Fig. 6 Flow diagram of the dynamics of seed banks and seedlings of A. melanoxylon, before and after a fire. Before fire, the germinated seeds came from the germination control of the aerial seed bank plus the corresponding one to each level of the soil seed bank. The fire scenario was inferred from the experiment and literature. It was assumed that fire destroyed the aerial seed bank and stimulated levels 1 and 2 (in the same

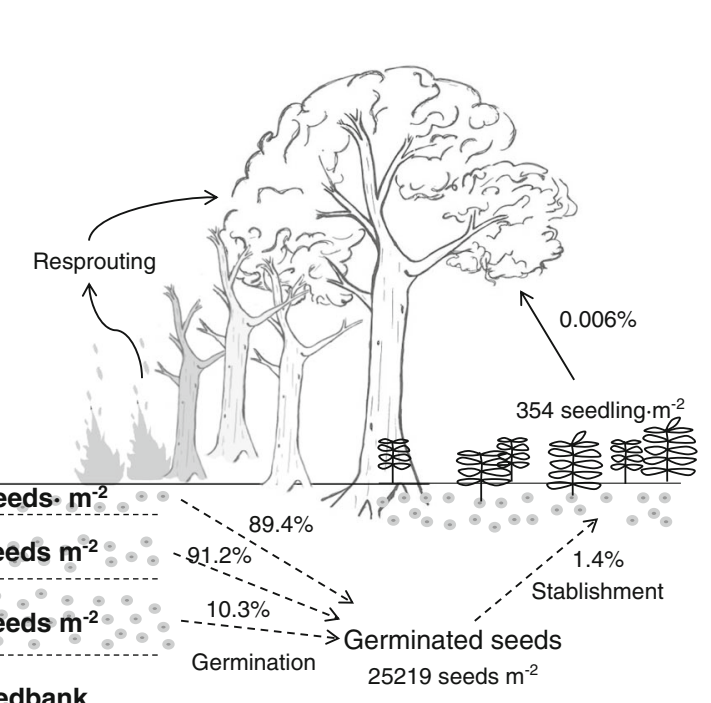

Soil seedbank

$\left(44640\right.$ seeds $\left.\cdot \mathrm{m}^{-2}\right)$

\section{After fire}

manner as $80{ }^{\circ} \mathrm{C}-10 \mathrm{~min}$ ) of soil seed bank but not level 3. Quantity of seeds present in the aerial and soil seed bank, as well as losses or transformation of individuals, are shown through the percentages of seeds that germinate, as well as the percentage of germinated seeds turned into new seedlings, and the percentage of seedlings that will reach the adult phase of the population in each of the two scenarios

control mechanisms of the species in an area already occupied. This species possesses a great plasticity, easily adapting to any environment and possessing very efficient propagation mechanisms.

Although we have not performed an A. melanoxylon control experiment, based on the general knowledge of the life cycle of this species, for small spaces, we propose to control the Australian Blackwood by some prescribed burning with a high frequency followed by uprooting of the emerged seedlings. For large spaces, we propose felling all trees (adult and seedlings) and uprooting all roots with minimal soil disturbance, to prevent mechanic scarification from stimulating the soil seed bank. After that, the soil should be colonized by one or several native species of rapid growth, highly competitive and that cover the soil fast enough to reduce, light to the ground and prevent acacia seedling from taking root. In Atlantic Europe, this species could be Ulex europaeus L. or Cytisus scoparius L (Link.). The germination of these species is stimulated by fire and also regrows (Reyes and Casal 2008; Reyes et al. 2009; Rivas et al. 2006). Although C. scoparius fire response is not as spectacular as that of $U$. europaeus, broom shrublands are taller and have more biomass than gorse shrublands (Reyes et al. 2000). In SW Europe, gorse shrublands and broom shrublands form almost monospecific communities that prevent the arrival of light to soil surface and seedling development of any species (Reyes et al. 2000). The control mechanism of the native species over the invasive species is expected to be similar to that described by Metlen and Callaway (2015) between Pinus ponderosa Dougl. ex Laws about Centaurea stoebe L.

\section{Conclusion}

The information given in this study as well as the understanding of great part of the reproductive biology of the species allows us to state that $A$. melanoxylon presents a serious invasive potential. It possesses seeds with high viability that forms an aerial seed bank, and another one edaphic, both of them very abundant. Starting from them, the recruiting of plants can occur with different temporality depending on the environmental conditions. Fire, maturation and scarification activate the seed bank and favour the massive recruiting of new plants. Its global strategy grants it enormous advantages over the native occupied vegetation. Preventing seedling early growth could be the key point to control A. melanoxylon.

Acknowledgements The authors are grateful to J. Casal for resolving some doubts. The authors are grateful for the suggestions of Chief editor, Erwin Dreyer, and Handling editor and the anonymous reviewers.

\section{Compliance with ethical standards}

Funding The study formed part of the project GESFIRE (AGL201348189-C2-R) financed by the Minister of Economy and Competitiveness, Government of Spain, and by FEDER. 


\section{References}

Arán D, García-Duro J, Reyes O, Casal M (2013) Fire and invasive species: modifications in the germination potential of Acacia melanoxylon, Conyza canadensis and Eucalyptus globulus. For Ecol Manag 302:7-13. doi:10.1016/j.foreco.2013.02.030

Bell DT (1999) Turner review no 1. The process of germination in Australian species. Aust J Bot 47:475-517

Blaskesley D, Allen A, Pellny TK, Roberts AV (2002) Natural and induced polyploidy in Acacia dealbata link and Acacia mangium Willd. Ann Bot 90:391-398

Bradbury GJ, Potts BM, Beadle CL (2011) Genetic and environmental variation in wood properties of Acacia melanoxylon. Ann For Sci 68:1363-1373. doi:10.1007/s13595-011-0115-x

Bradstock RA, Auld TD (1995) Soil temperatures during experimental bushfires in relation to fire intensity: consequences for legume germination and fire management in south-eastern Australia. J Appl Ecol 32:76-84

Calvo L, Hernández V, Valbuena L, Taboada A (2016) Provenance and seed mass determine seed tolerance to high temperatures associated to forest fires in Pinus pinaster. Ann For Sci 73(2):381-391

DAISE European Invasive Alien Specie Gateway (2008). Acacia melanoxylon. Available from: http://www.europe-aliens.org/ speciesFactsheet.do?speciesId=12793\#. Accessed 18 October 2016

Dick JTA, Alexander ME, Jeschke JM, Ricciardi A, MacIsaac HJ, Robinson TB, Kumschick S, Weyl OLF, Dunn AM, Hatcher MJ, Paterson RA, Farnsworth KD, Richardson DM (2014) Advancing impact prediction and hypothesis testing in invasion ecology using a comparative functional response approach. Biol Invasions 16:735753. doi:10.1007/s10530-013-0550-8

Ferrandis P, Herranz JM, Martínez-Sánchez JJ (1999) Effect of fire on hard-coated Cistaceae seed banks and its influence on techniques for quantifying seed bank. Plant Ecol 144(1):103-114

Ferrandis P, Bonilla M, Osorio Ldel C (2011) Germination and soil seed bank traits of Podocarpus angustifolius (Podocarpaceae): an endemic tree species from Cuban rain forests. Rev Biol Trop 59(3):10611069

Gibson MR, Richardson DM, Marchante E, Marchante H, Rodger JG, Stone GN, Byrne M, Fuentes-Ramírez A, George N, Harris C, Johnson SD, Le Roux JJ, Miller JT, Murphy DJ, Pauw A, Prescott MN, Wandrag EM, Wilson JRU (2011) Reproductive biology of Australian acacias: important mediator of invasiveness? Divers Distrib 17:911-933

Global Invasive Species Database (GISD), (2016) Species profile: Acacia melanoxylon. Available from http://www.iucngisd.org/gisd/species. php?sc=197 on 18-10-2016. [Accessed 18/October/2016]

González L, Souto XC, Reigosa MJ (1995) Allelopathic effects of Acacia melanoxylon R.Br. phyllodes during their decomposition. For Ecol Manag 77:53-63

González-Rabanal F, Casal M (1995) Effect of high temperatures and ash on germination of ten species from gorse shrubland. Vegetatio 116: $123-131$

Holmes PM (1989) Decay rates for buried Acacia seed populations of different density. S Afr J Bot 55:299-303

Hussain MI, González L, Reigosa MJ (2011) Allelopathic potential of Acacia melanoxylon on the germination and root growth of native species. Weed Biol Manage 11:18-28. doi:10.1111/j.1445-6664. 2011.00401.x

ISTA (2007) International rules for seed testing. International Seed Testing Association, Zurich. Switzerland

Jennings SM, Wilkinson GR, Unwin GL (2003) Response of blackwood (Acacia melanoxylon) regeneration to silvicultural removal of competition in regrowth eucalypt forests of north-west Tasmania, Australia. For Ecol Manag 177:75-83
Jiménez E, Vega JA, Pérez-Gorostiaga P, Fonturbel T, Fernández C (2010) Evaluation of sap flow density of Acacia melanoxylon R. Br. (blackwood) trees in overstocked stands in north-western Iberian peninsula. Eur J For Res 129:61-72

Knapic S, Tavares F, Pereira H (2006) Heartwood and sapwood variation in Acacia melanoxylon R. Br. trees in Portugal. Forestry 79(4):371380

Le Maitre DC, Gaertner M, Marchante E, Ens EJ, Holmes PM, Pauchard A, O'Farrell PJ, Rogers AM, Blanchard R, Blignaut J, Richardson DM (2011) Impacts of invasive Australian acacias: implications for management and restoration. Divers Distrib 17:1015-1029

Leino MW, Edqvist J (2010) Germination of 151-year old Acacia spp. Seeds Genet Resour Crop Evol 57:741-746

Lorenzo P, González L, Reigosa MJ (2010) The genus Acacia as invader: the characteristic case of Acacia dealbata link in Europe. Ann For Sci 67(101):1-11. doi:10.1051/forest/2009082

Mandle L, Bufford JL, Schmidt IB, Daehler CC (2011) Woody exotic plant invasions and fire: reciprocal impacts and consequences for native ecosystems. Biol Invasions 13:1815-1827

Marañon T (2001) Ecología del banco de semillas y dinámica de comunidades mediterráneas. In: Zamora Rodriguez R, Pugnaire de Iraola FI (eds) Ecosistemas mediterráneos. Análisis funcional. CSIC/AEET, Madrid

Marchante H, Freitas H, Hoffmann JH (2010) Seed ecology of an invasive species, Acacia longifolia (Fabaceae), in Portuguese dune ecosystems. Am J Bot 97(11):1780-1790

Méndez J, Morales G, Nascimento L, Otto R, Gallardo A, FernándezPalacios JM (2015) Understanding long-term post-fire regeneration of a fire-resistant pine species. Ann For Sci 72:609-619. doi:10. 1007/s13595-015-0482-9

Metlen KL, Callaway RM (2015) Native north American pine attenuates the competitive effects of a European invader on native grasses. Bioll Invasions 17:1227-1237. doi:10.1007/s10530-014-0790-2

Milton SJ, Hall AV (1981) Reproductive biology of Australian acacias in the south-western Cape province. South Africa Trans R Soc S Afr 44:465-485

Moya D, Espelta JM, Verkaik I, López-Serrano F, de las Heras J (2007) Tree density and site quality influence on Pinus halepensis mill. Ann For Sci 64:649-656. doi:10.1051/forest:2007043

O’Dowd DJ, Gill AM (1986) Seed dispersal syndromes of Australian Acacia. In: Murray D (ed) Seed Dispersal. Academic Press, New York, pp 87-121

Pinilla-Suárez JC, Molina-Brand MP, Briones R, Hernández-Cariaga G (2006) Opciones de productos a partir de la madera de acacia, y su promoción. Antecedentes de una experiencia con acacias en Chile. Bol Inf CIDEU 2:73-92

Reyes O, Casal M (2006) Seed germination of Quercus robur, $Q$. pyrenaica and $Q$. ilex and the effects of smoke, heat, ash and charcoal. Ann For Sci 63:205-212. doi:10.1051/forest:2005112

Reyes O, Casal M (2008) Regeneration models and plant regenerative types related to the intensity of fire in Atlantic shrubland and woodland species. J Veg Sci 19:575-589. doi:10.3170/2008-8-18412

Reyes O, Trabaud L (2009) Germination behaviour of 14 Mediterranean species in relation to fire factors: smoke and heat. Plant Ecol 202: 113-121. doi:10.1007/s11258-008-9532-9

Reyes O, Basanta M, Casal M, Díaz-Vizcaíno E (2000) Functioning and dynamics of Woody plant ecosystems in Galicia (NW Spain). In: Trabaud L (ed) Life and environment in the Mediterranean. WIT Press, Southamptom, pp 1-41

Reyes O, Casal M, Rego F (2009) Resprouting ability of six atlantic shrubs species. Folia Geobot 44:19-29. doi:10.1007/s12224-0099029-x

Reyes O, García-Duro J, Salgado J (2015a) Fire affects soil organic matter and the emergence of Pinus radiata seedlings. Ann For Sci 72: 267-275. doi:10.1007/s13595-014-0427-8 
Reyes O, Kaal J, Arán D, Gago R, Bernal J, García-Duro J, Basanta M (2015b) The effects of ash and black carbon on germination of different tree species. Fire Ecol 11(1):119-133. doi:10.4996/ fireecology

Richardson DM, Kluge RL (2008) Seed banks of invasive Australian Acacia species in South Africa: role in invasiveness and options form management. Perspect Plant Ecol Evol Syst 10:161-177

Rivas M, Reyes O, Casal M (2006) Influence of heat and smoke treatments on the germination of six leguminous shrubby species. Int $\mathrm{J}$ Wildland Fire 15:73-80

Sanz-Elorza M, Dana-Sánchez ED, Sobrino-Vesperinas E (eds) (2004) Atlas de las Plantas Alóctonas Invasoras en España. Dirección General para la Biodiversidad, Madrid, p 384
Searle SD (2000) Acacia melanoxylon: a review of variation among planted trees. Aust For 62:79-85

Stiehl-Alves EM, Martins-Corder MP (2006) Acacia mearnsii de wild. (Fabaceae) reproductive biology II: flowering and fructification phenology. Crop Breed Appl Biotechonol 6:144-150

Walters M, Milton SJ (2003) The production, storage and viability of seeds of Acacia karroo and A. nilotica in a grassy savanna in KwaZuluNatal. S Afr J Ecol 41:211-217

Wujeska-Klause A, Bossinger G, Tausz M (2015) Seedlings of two Acacia species from contrasting habitats show different photoprotective and antioxidative responses to drought and heatwaves. Ann For Sci 72:403-414. doi:10.1007/s13595-0140438-5 